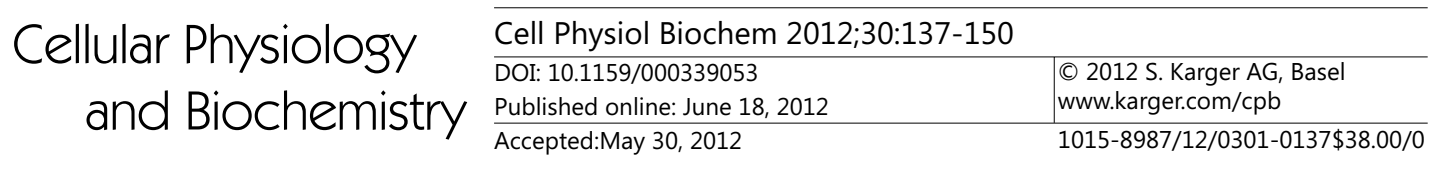

\title{
Genistein Stimulates Jejunal Chloride Secretion via Sex-dependent, Estrogen Receptor or Adenylate Cyclase Mechanisms
}

\author{
Layla Al-Nakkash
}

Department of Physiology, Midwestern University, Glendale

\section{Key Words}

Genistein $\bullet$ Estrogen receptors $\bullet$ Estradiol $\bullet$ Adenylate cyclase $\bullet$ Chloride secretion $\bullet$ Jejunum $\bullet$ Intestine $\cdot$ Signaling pathways

\begin{abstract}
Background/Aims: Daily subcutaneous injections with the phytoestrogen genistein, $600 \mathrm{mg} /$ $\mathrm{kg}$ genistein/day (600G) significantly increased intestinal chloride $\left(\mathrm{Cl}^{-}\right)$secretion $\left(\mathrm{I}_{\mathrm{sc}}, \mu \mathrm{A} / \mathrm{cm}^{2}\right)$ in C57BL/6J female and male murine jejunum after 1-2-weeks treatment. Methods and Results: In $600 \mathrm{G}$ females, basolateral application of the adenylate cyclase inhibitor MDL-12330A (10 $\mu \mathrm{M})$ significantly reduced basal and total $\mathrm{I}_{s c}$ in the presence of forskolin (27 and $40 \%$ respectively, $P<0.05$ ), with no effect in $600 \mathrm{G}$ males, suggesting that $600 \mathrm{G}$-mediated increases in $\mathrm{I}_{\mathrm{sc}}$ in females are due to an adenylate cyclase-dependent mechanism. Concomitant injections with the non-selective estrogen receptor (ER) antagonist ICI-182780 (25 mg/kg/day) resulted in a significant inhibition of basal $\mathrm{I}_{\mathrm{sc}}$ in males $(38 \%, P<0.05)$, but was without effect in females (further reinforcing an ER-independent mechanism of action). The ER $\alpha$-selective antagonist (MPP, $25 \mathrm{mg} / \mathrm{kg} /$ day) similarly significantly inhibited the basal $\mathrm{I}_{\mathrm{sc}}(37 \%, P<0.05)$ in males, whereas the ER $\beta$-selective antagonist (PHTPP, $25 \mathrm{mg} / \mathrm{kg} /$ day) was without effect, suggesting that 600G-mediated increases in $\mathrm{I}_{\mathrm{sc}}$ in male mice are due to an $\mathrm{ER} \alpha$-dependent mechanism. Jejunum ER $\alpha$ /actin expression was significantly increased by 600G in males. Compared to intact mice, orchiectomy has differing effects on 600G-mediated basal Isc; castration (CAST) abolished the 600G-mediated increases in $\mathrm{I}_{\mathrm{sc}}$ and ovariectomy (OVX) had no effect on the $600 \mathrm{G}$-stimulated increases in $\mathrm{I}_{\mathrm{sc}}$. Daily estradiol injections $(10-20 \mathrm{mg} / \mathrm{kg}$ body weight estradiol (10E2 or 20E2) had no effect in intact females, whereas 10E2 significantly increased basal $\mathrm{I}_{\mathrm{sc}}$ in OVX females. Conclusion: These data suggest that daily estradiol and genistein injections have differential sex-dependent mechanisms of action on murine intestinal $\mathrm{Cl}^{-}$secretion.
\end{abstract}




\section{Cellular Physiology and Biochemistry}

Cell Physiol Biochem 2012;30:137-150

\begin{tabular}{l|l}
\hline DOI: $10.1159 / 000339053$ & $\begin{array}{l}\text { C } 2012 \text { S. Karger AG, Basel } \\
\text { www.karger.com/cpb }\end{array}$ \\
Published online: June 18, 2012 & ww
\end{tabular}

Published online: June 18, 2012

\section{Introduction}

Genistein, a naturally occurring isoflavonic phytoestrogen found in high concentrations in soy products is structurally similar to estrogen $[1,2]$. Moreover, evidence suggests that genistein binds to estrogen receptors [3, 4], and has binding affinities to ER $\alpha$ and ER $\beta$ that are comparable to $17 \beta$-estradiol [5], although, a higher binding affinity for isoflavones to ER $\beta$ compared to ER $\alpha$ has also been described [6]. In general, the role of ER's in colonic tissue has commanded a greater focus compared to an examination of their role in the small intestine. Despite this, the evidence for the expression of ER's, let alone their role within the intestines is currently both contradictory and limited: i.e. a role for ER $\beta$ in the organization and architectural maintenance of the colon in mice [7]; a lack of expression of ER $\alpha$ in the small intestine and colon of young and old male and female rats [8], greater expression of $\mathrm{ER} \alpha$ than ER $\beta$ in colonic tissue from 8-weeks old rats, along with an isoflavone-induced (765 $\mathrm{mg} / \mathrm{kg}$ diet for 2-weeks) increased expression of ER $\alpha$ and concomitant decreased expression of ER $\beta$ [9], and, expression of both ER $\alpha$ and ER $\beta$ in the adult male and female murine small and large intestine [10].

Our previous evidence shows that mice fed a diet of $600 \mathrm{mg}$ genistein $/ \mathrm{kg}$ food for 4 weeks, yield serum concentrations of $\sim 7 \mu \mathrm{M}$ in female mice and $\sim 4 \mu \mathrm{M}$ in male mice [11], levels that are comparable to a soy milk diet in humans [12]. This dietary exposure to genistein (600 mg genistein $/ \mathrm{kg}$ food for 4-weeks) stimulated basal $\mathrm{Cl}^{-}$secretion across freshly isolated segments of jejunum from female mice, but not male mice [11]. Moreover, we have recently shown that daily genistein $(600 \mathrm{mg}$ genistein/kg body weight, $600 \mathrm{G})$ subcutaneous (s.c.) injections for a period of 1-week in female mice, or 2-weeks in male mice, also significantly increases serum genistein levels $(\sim 5 \mu \mathrm{M}$ and $\sim 4 \mu \mathrm{M}$ respectively), compared to $0 \mathrm{G}$ female and male controls, which had non-detectable serum genistein levels [13]. These data suggest that regardless of route of administration of genistein, diet or daily s.c. injections, serum genistein levels are measurably increased. The advantage of the use of daily s.c. injections route of genistein administration versus diet, is that it yields less variable and more sustained elevations in intestinal anion secretion, as we have shown previously $[11,13]$.

The manipulation of tissue function by genistein has been described in several tissues; Noel et al. [14] demonstrated that s.c. injection of $50 \mu \mathrm{M}$ genistein (or MPB-07), in the presence of isoprenaline $(10 \mu \mathrm{M})$, induced salivary secretion in $\mathrm{Cftr}^{+/+}$mice, and more recently, Tuo et al. provided evidence of genistein-stimulated increases in duodenal $\mathrm{HCO}_{3}$ secretion, mediated via an ER and PI3K-dependent pathway $[15,16]$.

We have recently described the effects of 1- or 2-weeks with daily sc. genistein injections, $600 \mathrm{mg} / \mathrm{kg}$ body weight/day (600G), or the vehicle control (0 mg/kg body weight/day, 0G), on small intestinal (jejunum) epithelial anion secretion (using freshly excised jejunum segments) in female and male mice [13]; (1) basal $I_{\mathrm{sc}}$ was significantly increased with daily 600G injections, after 1 -week in females $\left(215.9 \pm 13.1 \mu \mathrm{A} / \mathrm{cm}^{2}(\mathrm{n}=15)\right.$ and $126.5 \pm 10.1$ $\mu \mathrm{A} / \mathrm{cm}^{2}(\mathrm{n}=8)$ respectively, $\left.P<0.05\right)$ and 2-weeks in males $\left(186.6 \pm 7.6 \mu \mathrm{A} / \mathrm{cm}^{2}(\mathrm{n}=5)\right.$ and $100.8 \pm 18.2 \mu \mathrm{A} / \mathrm{cm}^{2}(\mathrm{n}=7)$ respectively, $\left.P<0.05\right)$, (2) there was some $600 \mathrm{G}$-dependent CFTR-mediated contribution towards the $\mathrm{Cl}^{-}$secretion, and (3) there was a modest $5 \%$ increase in CFTR trafficking to the apical membrane in males (but not females).

Here, we aimed to further understand genistein's mechanism of action on $\mathrm{Cl}^{-}$secretion in jejunum, after treatment for 1-week in females and 2-weeks in males with daily subcutaneous injection of genistein (600 mg/kg body weight/day, 600G). Pharmacological antagonists for the estrogen receptors (ER's) were used to assess whether the stimulatory action on jeunual $\mathrm{Cl}^{-}$secretion induced by 600G, involved ER $\alpha$ and/or ER $\beta$. We examined the effects of genistein in the presence and absence of endogenous sex-hormones using ovariectomized females and castrated males, and the effects of genistein and estradiol were compared. Moreover, we examined the effects of several pharmacological inhibitors 


\begin{tabular}{rl|l} 
Cellular Physiology & $\begin{array}{l}\text { Cell Physiol Biochem 2012;30:137-150 } \\
\text { and Biochemistry }\end{array}$ & \\
\cline { 2 - 3 } Dublished online: June 18, 2012 & $\begin{array}{l}\text { O 2012 S. Karger AG, Basel } \\
\text { www.karger.com/cpb }\end{array}$ \\
\cline { 2 - 3 } & Al-Nakkash: Genistein: Sex-dependent Mechanisms of Action in Jejunum
\end{tabular}

to determine intracellular signaling pathways. We hypothesized that genistein would have a gender-dependent mechanism of action.

\section{Materials and Methods}

Mice

Male and female C57BL/6J mice were purchased from Jackson Laboratory (Bar Harbor, ME) at 4-6 weeks of age and housed in an animal care facility with 12:12-hour light-dark cycle. Mice consumed food and water ad libitum. Body weight and general health were monitored biweekly. Mice were fed a casein based genistein-free diet throughout the study and randomly assigned to one of the following injection groups; 600G (600 mg/kg body weight genistein), or 0G (0 mg/kg body weight genistein - genistein free) for either 1- or 2-weeks depending on the sex (males 2-weeks and females 1-week). Subsets of mice were assigned to receive concomitant injections with either 7a,17b-[9-[4,4,5,5,5-pentafluoropentyl)sulfinyl]non yl] estra-1,3,5(10)-triene-3,17-diol (ICI-182780 - a non-selective ER antagonist, $25 \mathrm{mg} / \mathrm{kg} /$ day), 1,3-Bis(4hydroxyphenyl)-4-methyl-5-[2-piperidinylethoxy)phenol]-1H-pyrazole dihydrochloride (MPP - an ER $\alpha$ antagonist, $25 \mathrm{mg} / \mathrm{kg} /$ day), or 4-[2-phenyl-5,7-bis9trifluoromethyl)pyrazolol[1,5-a]pyrimidin-3-yl]phenol (PHTPP - an ER $\beta$ antagonist, $25 \mathrm{mg} / \mathrm{kg} /$ day), for the last 5 days of the study to determine involvement of estrogen receptors. Additional groups of female mice were injected with either $10 \mathrm{mg} / \mathrm{kg}$ body weight estradiol (10E2) or $20 \mathrm{mg} / \mathrm{kg}$ body weight estradiol (20E2) to compare the effects of estradiol (E2) with those of genistein.

At the end of the injection study period, mice were asphyxiated in an atmosphere of $100 \% \mathrm{CO}_{2}$, followed by surgical thoracotomy to induce pneumothorax. Animal care and treatments were conducted in accordance with established guidelines and all protocols were approved by Midwestern University IACUC. Diets. The casein-based diet was prepared by Dr. R. S. MacDonald (Department of Nutrition, Iowa State University) and contained $0 \mathrm{G}$ and had an estimated energy content of $16.28 \mathrm{~kJ} / \mathrm{g}$. Diet composition is described previously in Al-Nakkash et al. [11].

\section{Estrogen receptor, ER $\alpha$ and ER $\beta$, western blot}

At collection, segments of cleaned jejuna were immediately snap frozen in liquid nitrogen and stored at $-80^{\circ} \mathrm{C}$. Jejuna were later prepared for western blot analysis by homogenization. The western blot protocol was similar to that described previously [13]. Briefly, samples were analyzed for protein content, and ran on $4-12 \%$ Tris-Glycine gels at $150 \mathrm{~V}$ for $\sim 1.5$ hours (for both $\mathrm{ER} \alpha$ and ER $\beta$ ). Transfer was for 2 hours at $30 \mathrm{~V}$ on ice. Blots were incubated with primary antibody to either ER $\alpha$ or ER $\beta$ (1:500 and 1:250 dilutions respectively) overnight at $4^{\circ} \mathrm{C}$. After washing, blots were incubated with donkey anti-mouse IgG, HRP conjugated secondary antibody (1:5000 dilution for ER $\alpha$ and 1:1000 for ER $\beta$ ) for 1 hour at room temperature. To re-probe for actin: blots were incubated with anti-actin primary antibody (1:7500 or 1:20000 dilutions for ER $\alpha$ and ER $\beta$ respectively) overnight at $4^{\circ} \mathrm{C}$. Blots were washed and then re-incubated with an anti-mouse IgG, HRP conjugated secondary antibody (1:15000 or 1:5500 dilutions for ER $\alpha$ and ER $\beta$ respectively). Blots were visualized using ECL (Amersham, Piscataway, NJ). Images were taken and analyzed using the STORM 860 scanner (Molecular Dynamics, Piscataway, NJ) and image quant (Molecular Dynamics, Piscataway, NJ).

\section{Bioelectric measurement of intestinal secretion}

Via an abdominal incision, $\sim 5 \mathrm{~cm}$ of mid-jejunum was removed and placed in ice-cold oxygenated Krebs bicarbonate ringer (KBR). Each mouse yielded 2-3 jejunum pieces, isolated as described previously [11, 13, 17-19]. Jejunum intact (whole mount, un-stripped) sections mounted in the Ussing chambers had $0.3 \mathrm{~cm}^{2}$ exposed surface area. Whole mount jejunum has been shown to respond to acute application of genistein with favorable time courses. Evidence published from Hamilton's lab [20, 21] provides support for genistein's stimulatory action on intact jejunum when applied acutely, and, as with our studies, it appears that the presence of the circular and longitudinal muscle layers surrounding the jejunum did not impede access of chemicals to the epithelium, as exhibited by rapid $\mathrm{I}_{\mathrm{sc}}$ responses with the addition of forskolin or bumetanide. Transepithelial short circuit current $\left(\mathrm{I}_{\mathrm{sc}} \mu \mathrm{A} / \mathrm{cm}^{2}\right)$ was measured via an automatic voltage clamp (VCC-600, Physiologic Instruments, San Diego, CA) and the experimental conditions and methods were as previously described [22]. Intestinal tissue pieces were maintained in $1 \mu \mathrm{M}$ indomethacin (minimizing tissue exposure to endogenously generated prostanoids due to manipulation and mounting of the tissue, [23]. Glucose $(10 \mathrm{mM})$ was added to the serosal KBR bath and mannitol $(10 \mathrm{mM})$ substituted for glucose in the mucosal KBR bath, to avoid an inward current due to $\mathrm{Na}^{+}$-coupled glucose transport [22] 


\section{Cellular Physiology Cell Physiol Biochem 2012;30:137-150 and Biochemistry

\begin{tabular}{l|l}
\hline DOI: $10.1159 / 000339053$ & $\begin{array}{l}\text { C 2012 S. Karger AG, Basel } \\
\text { www.karger.com/cpb }\end{array}$ \\
Published online: June 18, 2012 & Pwo \\
\hline
\end{tabular} \\ Al-Nakkash: Genistein: Sex-dependent Mechanisms of Action in Jejunum}

Fig. 1. Effect of signaling pathway inhibitors on basal and cAMP-stimulated $\mathrm{I}_{\mathrm{sc}}$ in female and male mice. A. Average basal $I_{s c}$ from female and male mice injected with either 600G (solid bars, $n=5-15$ ), or 0G (open bars, $\mathrm{n}=4-9)$. B. Average total $\mathrm{I}_{\mathrm{sc}}$ in the presence of forskolin $(10 \mu \mathrm{M}$, bilateral) from female and male mice injected with either 600G (solid bars, $n=5-15$ ), or 0G (open bars, $n=4-9$ ). Values are means \pm SEM. * denotes significant inhibition from 600G alone, $P<0.05$.

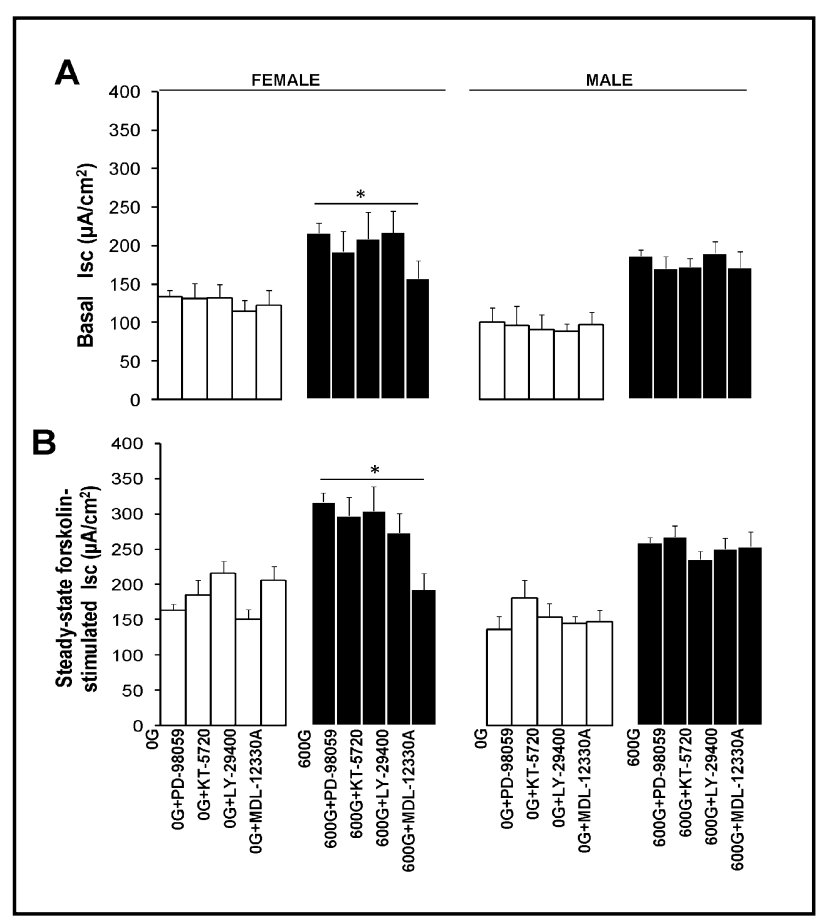

Once mounted, the serosal side was exposed to tetrodotoxin $(0.1 \mu \mathrm{M})$, minimizing variations in intrinsic intestine neural tone [24]. Intrinsic neural tone limits the absorptive capacity of the murine mucosa (decreased I denotes neural block). Experimental protocols: Protocol 1: Tissues were exposed to KBR (20 min) and steady-state basal $I_{s c}$ measured at that time. cAMP-dependent anion secretion was assessed by bilateral application of $10 \mu \mathrm{M}$ forskolin (at time $20 \mathrm{~min}$ ) and total $\mathrm{I}_{\mathrm{sc}}$ in the presence of forskolin was noted (at time $50 \mathrm{~min}$ ). Glucose $\left(10 \mathrm{mM}\right.$, mucosal) was added at the end of each experiment to stimulate $\mathrm{Na}^{+}-$ coupled glucose transport and assess tissue viability (as denoted by $>10 \%$ increase in $\mathrm{I}_{\mathrm{sc}}$ ). Tissues failing to respond to glucose within this parameter were discarded. Protocol 2: Tissues were exposed to KBR (20 $\mathrm{min}$ ) and steady-state basal I measured at that time. A signaling pathway inhibitor was added (basolateral, at time $20 \mathrm{~min}$ ): MAPK inhibitor, 2-(2-Amino-3-methoxyphenyl)-4H-1-benzopyran-4-one (PD-98059, 10 $\mu \mathrm{M})$; PKA inhibitor, (9S,10S,12R)-2,3,9,10,11,12-Hexahydro-10-hydroxy-9-methyl-1-oxo-9,12-epoxy-1Hdiindolo[1,2,3-fg:3',2',1'-kl]pyrrolo[3, 4i] [1, 6] benzodiazocine-10-carboxylic acid hexyl ester (KT-5720, 1 $\mu \mathrm{M}$ ); PI3K inhibitor, 2-(4-Morpholinyl)-8-phenyl-1(4H)-benzopyran-4-one hydrochloride (LY-294002, 20 $\mu \mathrm{M})$; adenylate cyclase inhibitor, cis-N-(2-Phenylcyclopentyl)-azacyclotridec-1-en-2-amine hydrochloride (MDL-12330A, $10 \mu \mathrm{M}$ ), and its effect noted at time $40 \mathrm{~min}$. cAMP-dependent anion secretion was assessed by bilateral application of $10 \mu \mathrm{M}$ forskolin (at time $40 \mathrm{~min}$ ) and the steady-state forskolin response (at time $70 \mathrm{~min})$. Glucose (10 mM, mucosal) was added at the end of each experiment. Solution: $\mathrm{Cl}^{-}$-containing KBR contained the following (in mM): $115 \mathrm{NaCl}, 25 \mathrm{NaHCO}_{3}, 5 \mathrm{KCl}, 1.2 \mathrm{MgCl}_{2}$ and $1.2 \mathrm{CaCl}_{2}, \mathrm{pH} 7.4$.

\section{Chemicals}

Forskolin was purchased from Calbiochem (San Diego, CA). ICI-182780, MPP and PHTPP were purchased from Tocris Bioscience (Ellisville, MO). PD-98059, KT-5720, LY-294002, and MDL-12330A were all purchased from Sigma Aldrich (St Louis, MO). Western blot antibodies: ER $\alpha$ and ER $\beta$ (Santa Cruz Biotechnology Inc, CA), donkey anti-mouse IgG, HRP conjugated (Santa Cruz Biotechnology Inc, CA), AntiActin (Millipore, Temecula, CA) and anti-mouse IgG, HRP conjugated (Upstate/Millipore, Temecula, CA). All other chemicals were obtained from Sigma Chemical Co. (St. Louis, MO).

\section{Statistics}

Data are expressed as mean \pm SEM. Numbers in parentheses are numbers of tissues used from separate individual mice. One-way ANOVA with Neuman- Keul's multiple comparison test or t-tests were performed using GraphPad (San Diego, CA). $P<0.05$ was considered statistically significant. 


\section{Cellular Physiology Cell Physiol Biochem 2012;30:137-150

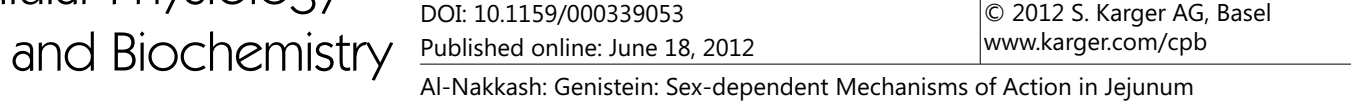

Fig. 2. Effect of estrogen receptor antagonists on basal and cAMP-stimulated $\mathrm{I}_{\mathrm{sc}}$ in female and male mice. A. Average basal and total $\mathrm{I}_{\mathrm{sc}}$ in the presence of forskolin (10 $\mu \mathrm{M}$, bilateral) from female mice injected for 1-week with either 600G (solid squares, $\mathrm{n}$ =11), 600G+ICI 182780 (open triangles, $n$ = 5), $0 \mathrm{G}$ (open squares, $\mathrm{n}=8$ ) and $0 \mathrm{G}+\mathrm{ICI}$ $182760(-\mathrm{X}-, \mathrm{n}=7)$. B. Average basal and total $\mathrm{I}_{\mathrm{sc}}$ in the presence of forskolin (10 $\mu \mathrm{M}$, bilateral) from male mice injected for 2-weeks with either 600G (solid squares, $\mathrm{n}=5$ ), 600G+ICI 182780 (open triangles, $\mathrm{n}=6$ ), 600G+MPP (solid diamonds, $\mathrm{n}=$ 5), 600G+PHTPP (gray squares, $n=8$ ), $0 \mathrm{G}$ (open squares, $\mathrm{n}=7$ ) and $0 \mathrm{G}+\mathrm{ICI} 182760$ ($\mathrm{X}-, \mathrm{n}=5$ ). Values are means \pm SEM. * denotes significant inhibition from same time point with $600 \mathrm{G}$ alone, $P<0.05$.

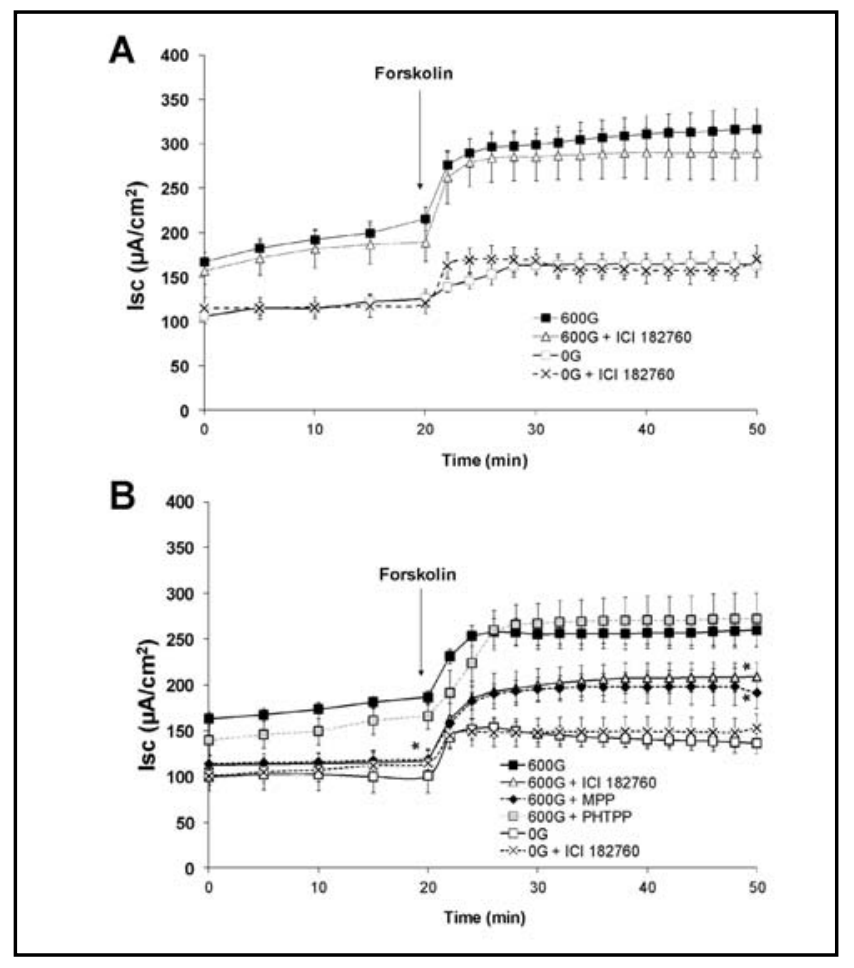

\section{Results}

Effect of signaling pathway inhibitors on intestinal Isc

We examined the effect of four signaling pathway inhibitors on basal and total $\mathrm{I}_{\mathrm{sc}}$ in the presence of forskolin, in male and female mice injected with either 600G or 0G (Fig. 1). There was no effect of the basolateral addition of the MAPK inhibitor PD-98059 (10 $\mu \mathrm{M})$, PKA inhibitor KT-5720 $(1 \mu \mathrm{M})$ or the PI3K inhibitor LY-294002 $(20 \mu \mathrm{M})$ on basal $\mathrm{I}_{\mathrm{sc}}$ or total $\mathrm{I}_{\mathrm{sc}}$ in the presence of forskolin, in males or females injected with either 0G or 600G.

In $600 \mathrm{G}$ females, the adenylate cyclase inhibitor MDL-12330A $(10 \mu \mathrm{M})$ significantly inhibited both the basal $\mathrm{I}_{\mathrm{sc}}$ (by $27 \%, P<0.05$ ) and total $\mathrm{I}_{\mathrm{sc}}$ in the presence of forskolin (by $40 \%$, $P<0.05$, Fig. 1A, B). No effect of MDL-12330A was observed in the other groups. These data suggest that the adenylate cyclase signaling pathway is involved in the genistein-mediated increases in anion transport in females, but does not have a role in the 600G-stimulated increase in intestinal secretion in males.

\section{Effect of ER antagonists on intestinal Isc}

Since genistein is structurally similar to estrogen, we aimed to determine the role of ER's in mediating the 600G-stimulated increases in basal and total $\mathrm{I}_{\mathrm{sc}}$ in the presence of forskolin. In female mice, concomitant injections of the non-specific ER antagonist ICI-182780 (25 $\mathrm{mg} / \mathrm{kg} /$ day) with $0 \mathrm{G}$ or $600 \mathrm{G}$ injections, had no effect on either the basal $\mathrm{I}_{\mathrm{sc}}$ or the total $\mathrm{I}_{\mathrm{sc}}$ in the presence of forskolin, compared to $0 \mathrm{G}$ or $600 \mathrm{G}$ alone (Fig. 2A). These data suggest that genistein-mediated increases in basal and total $\mathrm{I}_{\mathrm{sc}}$ in the presence of forskolin in female mice are not mediated via an ER-mediated pathway.

Male 600G mice concomitantly injected with the non-specific ER antagonist ICI-182780 significantly decreased the basal $\mathrm{I}_{\mathrm{sc}}$ compared to $600 \mathrm{G}$ alone (by $38 \%, P<0.05$, Fig. $2 \mathrm{~B}$ ) and decreased the total $\mathrm{I}_{\mathrm{sc}}$ in the presence of forskolin compared to $600 \mathrm{G}$ alone (by $20 \%, P<$ 0.05 , Fig. 2B). There was no effect of ICI-182780 in 0G males (Fig. 2B). These data suggest that in males, 600G-mediated increases in basal and total $\mathrm{I}_{\mathrm{sc}}$ in the presence of forskolin are mediated via an ER-dependent pathway.

To further elucidate which ER's were responsible, we concomitantly injected two additional subgroups of male 600G mice with either an ER $\alpha$-selective antagonist (MPP, 25 


\section{Cellular Physiology Cell Physiol Biochem 2012;30:137-150

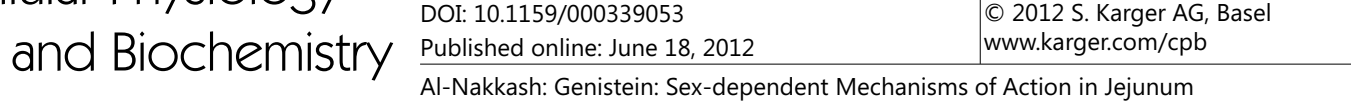
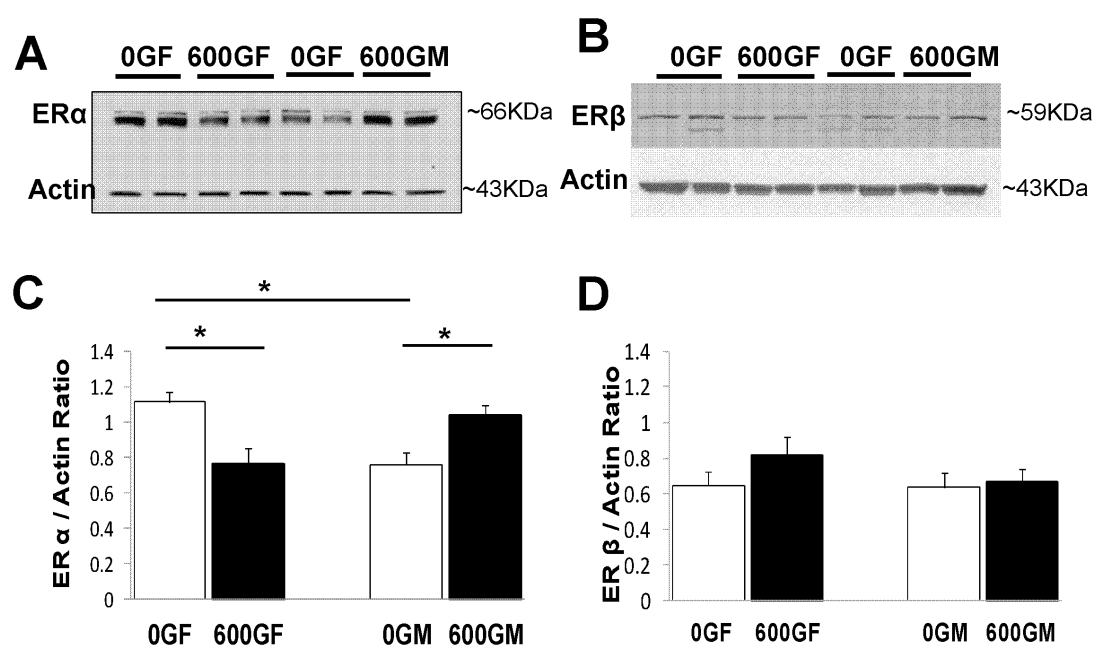

Fig. 3. Effect of genistein treatment on total ER $\alpha$ and ER $\beta$ protein expression in female and male murine jejunum. A. Typical western blot demonstrating ER $\alpha$ and actin expression in jejunum from 2 samples each of $600 \mathrm{G}$ and $0 \mathrm{G}$ treated female and male mice. ER $\alpha$ and actin bands were observed at $\sim 66 \mathrm{KDa}$ and 43KDa respectively. B. Typical western blot demonstrating ER $\beta$ and actin expression in jejunum from 2 samples each of $600 \mathrm{G}$ and $0 \mathrm{G}$ treated female and male mice. ER $\beta$ and actin bands were observed at $~ 59 \mathrm{KDa}$ and $43 \mathrm{KDa}$ respectively. C. Average ER $\alpha$ /actin ratio comparing 600G (solid bars) and 0G (open bars) treated male and female mice ( $n=11$ /group). D. Average ER $\beta$ /actin ratio comparing 600G (solid bars) and 0G (open bars) treated male and female mice ( $\mathrm{n}=6-8$ /group). Values are means \pm SEM. * denotes significance, $P<$ 0.05 .

$\mathrm{mg} / \mathrm{kg} /$ day) or an ER $\beta$-selective antagonist (PHTPP, $25 \mathrm{mg} / \mathrm{kg} /$ day). Co-injection with MPP and 600G significantly decreased all $\mathrm{I}_{\mathrm{sc}}$ 's compared to $600 \mathrm{G}$ alone; basal $\mathrm{I}_{\mathrm{sc}}$ decreased by $37 \%$ $(P<0.05)$ and total $\mathrm{I}_{\mathrm{sc}}$ in the presence of forskolin decreased by $27 \%(P<0.05$, Fig 2B). There was no effect of co-injection with PHTPP (Fig 2B). These data suggest that 600G-mediated increases in basal and total $\mathrm{I}_{\mathrm{sc}}$ in the presence of forskolin in male mice are mediated via an ER $\alpha$-dependent pathway.

\section{Effect of genistein on intestinal ER $\alpha$ and ER $\beta$ protein expression}

Since our transepithelial short circuit current measures using ER antagonists suggested that genistein-mediated increases in basal and total $\mathrm{I}_{\mathrm{sc}}$ in the presence of forskolin were mediated in male mice (but not females) via an ER $\alpha$-dependent pathway, we next aimed to determine whether or not $\mathrm{ER} \alpha$ and/or ER $\beta$ expression was increased in males versus females, and/or changed by the genistein treatment. Standard western blot techniques were utilized to determine total jejunal ER $\alpha$ or ER $\beta$ expression (at $\sim 66$ or $\sim 59$ KDa respectively), normalized to actin $(\sim 43 \mathrm{KDa}$ ). ER $\alpha$ /actin expression was significantly decreased in $0 \mathrm{G}$ males (by $32 \%$, $P<0.05$ ) compared to $0 \mathrm{G}$ females; suggesting a gender-dependent difference under resting control conditions (Fig. 3A, C). Moreover, genistein treatment (600G) had differing effects on ER $\alpha$ expression; 600G significantly decreased $E R \alpha$ expression in females by $\sim 31 \%(n=11$, $P<0.05$ ), whereas 600G significantly increased ER $\alpha$ expression in males by $\sim 27 \%$ ( $\mathrm{n}=11, P$ $<0.05$, Fig. $3 \mathrm{~A}, \mathrm{C}$ ). These data suggest that $\mathrm{ER} \alpha$ expression is differentially regulated in male and female mice by genistein. There was no effect of either sex or genistein-treatment on ER $\beta$ expression in jejunum (Fig. 3B, D).

Effect of genistein and orchiectomy on intestinal Isc

We compared the effect of $600 \mathrm{G}$ on intact mice versus those with orchiectomy (ovariectomized (OVX) females, or castrated (CAST) males). Both intact and OVX females 


\section{Cellular Physiology Cell Physiol Biochem 2012;30:137-150

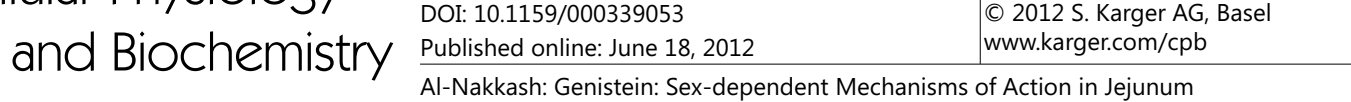

Fig. 4. Effect of $600 \mathrm{G}$ on average basal and cAMP-stimulated $\mathrm{I}_{\text {sc }}$ in intact and orchiectomized female and male mice. A. A comparison of the basal and total $\mathrm{I}_{\mathrm{sc}}$ in the presence of forskolin $(10 \mu \mathrm{M}$, bilateral) responses from female mice injected for 1-week with either 600G; intact (filled squares, $\mathrm{n}=15$ ), OVX (filled diamonds, $\mathrm{n}=14$ ), or 0G; intact (open squares, $\mathrm{n}=8$ ), OVX (open diamonds, $\mathrm{n}$ $=10$ ). B. A comparison of the basal and total $\mathrm{I}_{\mathrm{sc}}$ in the presence of forskolin (10 $\mu \mathrm{M}$, bilateral) responses from male mice injected for 2-weeks with either 600G; intact (filled squares, $n=5$ ), CAST (filled diamonds, $n=5$ ), or 0G; intact (open squares, $n=5$ ), CAST (open diamonds, $n$ $=7$ ). Values are mean \pm SEM, $*$ denotes significant difference from $0 \mathrm{G}, P<0.05$.

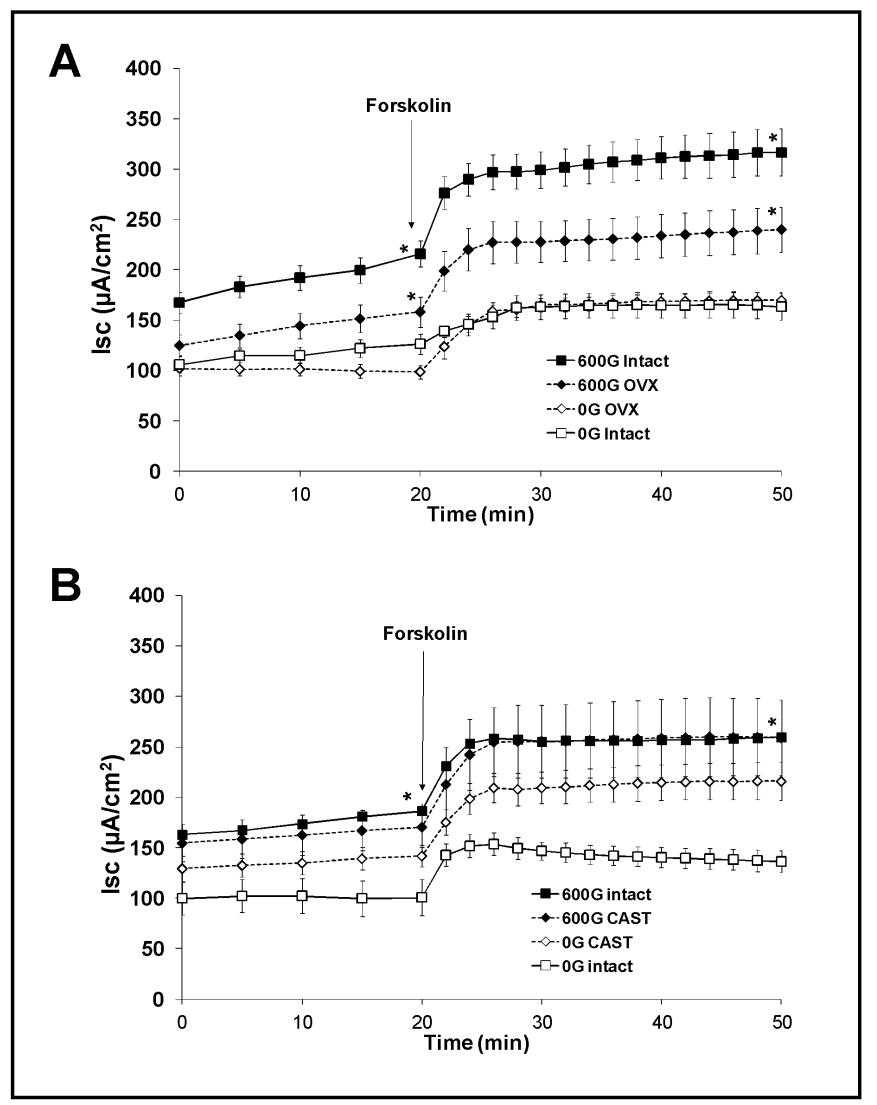

\begin{tabular}{llcc}
\hline Parameter & Group & OG & $600 \mathrm{G}$ \\
& & & $215.9 \pm 13.1(15)^{*}$ \\
Basal & Intact Female & $126.5 \pm 10.1(8)$ & $158.9 \pm 15.2(14)^{* *}$ \\
& OVX Female & $96.8 \pm 6.8(10)$ & $186.6 \pm 7.6(5)^{*}$ \\
Basal & Intact Male & $100.8 \pm 18.2(7)$ & $170.5 \pm 20.4(5)$ \\
& CAST Male & $141.9 \pm 11.1(5)$ & $316.6 \pm 23.4(15)^{*}$ \\
SS-Fsk & Intact Female & $163.4 \pm 13.6(8)$ & $240.5 \pm 22.3(14)^{* *}$ \\
& OVX Female & $169.9 \pm 7.9(10)$ & $259.8 \pm 37.8(5)^{*}$ \\
SS-Fsk & Intact Male & $136.5 \pm 10.9(7)$ & $259.1 \pm 37.8(5)$ \\
& CAST Male & $215.9 \pm 18.5(5)$ & \\
\hline
\end{tabular}

Table 1. Effect of orchiectomy and genistein on Isc:The following basal and total Isc in the presence of forskolin (SS-Fsk) Isc ( $\mu \mathrm{A} / \mathrm{cm} 2)$ measures were taken in both female and male mice (ovariectomized (OVX), castrated (CAST), or intact), injected with 600G (genistein-treated), or 0G (genistein-free). Data is expressed as mean \pm SEM (numbers in parentheses are numbers of animals). * denotes significant difference to $0 \mathrm{G}(\mathrm{P}$ $<0.05)$, \# denotes significant difference to intact counterparts $(\mathrm{P}<0.05)$.

injected with 600G had significantly increased basal $\mathrm{I}_{\mathrm{sc}}$ (by $\sim 1.6$-fold, $P<0.05$ ) and elevated total $\mathrm{I}_{\mathrm{sc}}$ in the presence of forskolin (by $\sim 1.4-2.0$-fold, $P<0.05$ ) compared to their 0G controls (Fig. 4, Table 1). Intact females responded with a significantly greater increase in both basal $\mathrm{I}_{\mathrm{sc}}$ (by 1.4-fold, $P<0.05$ ) and total $\mathrm{I}_{\mathrm{sc}}$ in the presence of forskolin (by 1.3 -fold, $P<0.05$ ) compared to the OVX females (Fig. $4 \mathrm{Ac}$, Table1). Basal $\mathrm{I}_{\mathrm{sc}}$ was similar for both $0 \mathrm{G}$ controls in intact and OVX groups (Fig. 4A, Table 1).

Only intact 600G males had a significantly increased basal $\mathrm{I}_{\mathrm{sc}}$ (by 1.9-fold, $P<0.05$ ) and total $\mathrm{I}_{\mathrm{sc}}$ in the presence of forskolin (by 1.8 -fold, $P<0.05$ ) compared to their respective 0G controls (Fig. 4B, Table 1). There was no effect of 600G in CAST males when compared 


\section{Cellular Physiology $\quad$ Cell Physiol Biochem 2012;30:137-150

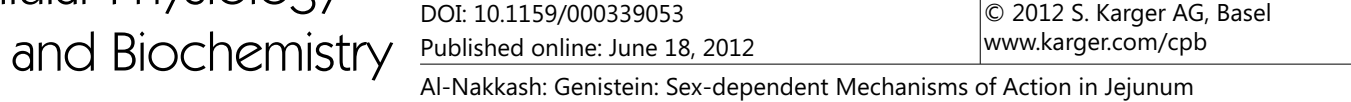

Fig. 5. Effect of $600 \mathrm{G}$ and estradiol on average basal and cAMP-stimulated $\mathrm{I}_{\text {sc }}$ in intact and orchiectomized female mice. A. Comparison of the basal and total $\mathrm{I}_{\mathrm{sc}}$ in the presence of forskolin $(10 \mu \mathrm{M}$, bilateral) responses from intact female mice injected for 1-week with either 600G (filled squares, $\mathrm{n}=15$ ), 10E2 (filled triangles, $\mathrm{n}=8$ ), 20E2 (filled circles, $\mathrm{n}=$ 7 ), or $0 \mathrm{G}$ (open squares, $\mathrm{n}=8$ ). B. Comparison of the basal and total $I_{s c}$ in the presence of forskolin $(10 \mu \mathrm{M}$, bilateral) responses from OVX female mice injected for 1-week with either 600G (filled squares, $\mathrm{n}=14$ ), 10E2 (filled triangles, $\mathrm{n}=10$ ), 20E2 (filled circles, $\mathrm{n}$ $=10$ ), or $0 G$ (open squares, $n=12$ ). Values are mean $\pm \mathrm{SEM}, *$ denotes significant difference from $0 \mathrm{G}, P<0.05$.

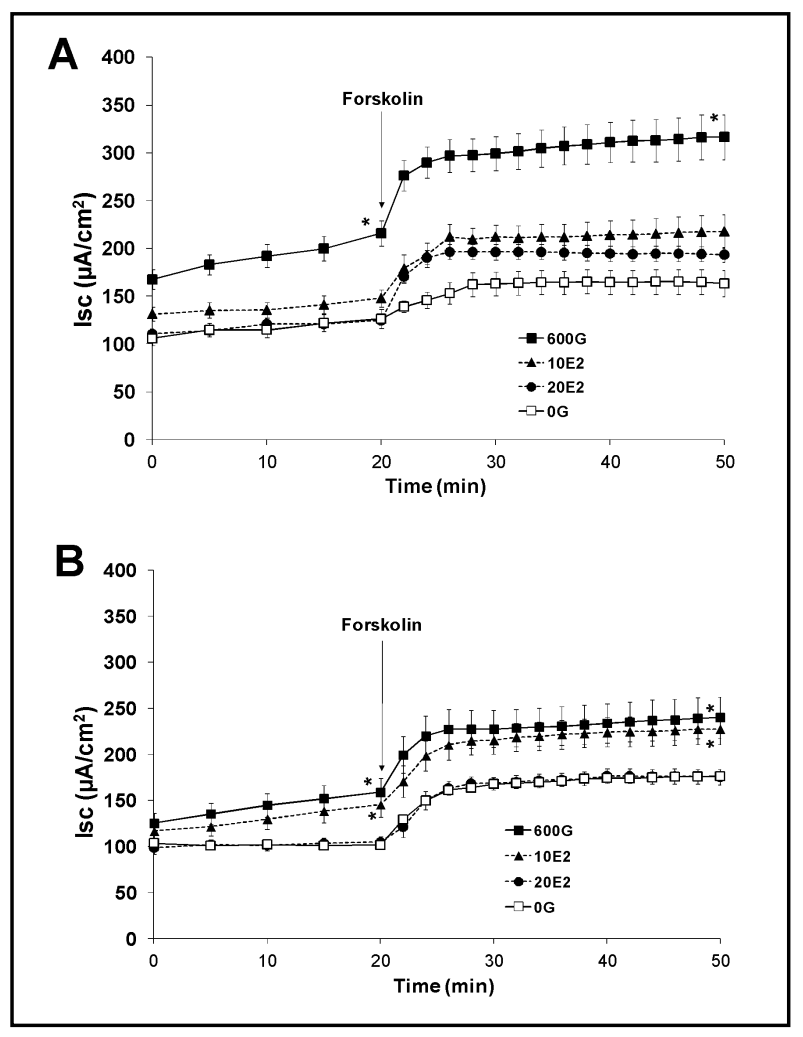

to their 0G controls, and, of note, basal $\mathrm{I}_{\mathrm{sc}}$ was significantly increased in 0G CAST males compared to $0 \mathrm{G}$ intact males (Fig. 4B, Table1). These data suggest that orchiectomy, i.e. the absence of endogenous sex hormones, changes the responsiveness of male and female mice to 600G; OVX females respond similarly to intact females (OVX mimics the intact 600Gmediated increase in $\mathrm{I}_{\mathrm{sc}}$ ), whereas CAST males do not respond similarly to intact males (CAST eliminates the $600 \mathrm{G}$-mediated increase in $\mathrm{I}_{\mathrm{sc}} \mathrm{s}$.

\section{Effect of genistein and estradiol on intestinal Isc.}

Given the estrogen-like characteristics of genistein (i.e. structurally similar to estrogen), we compared the effect of two concentrations of daily estradiol injections with 600G on female intact and OVX mice. In intact females, neither 10E2 nor 20E2 had an effect on basal $I_{s c^{\prime}}$ and both mimicked 0G controls, when compared to 600G (Fig. 5A). The total $I_{s c}$ in the presence of forskolin in intact females with 10E2 or 20E2 was significantly less than with 600G (by $32 \%$ and $39 \%$ respectively, $P<0.05$, Fig. 5A).

In OVX females, $10 \mathrm{E} 2$ mimicked $600 \mathrm{G}$ by significantly increasing basal $\mathrm{I}_{\mathrm{sc}}(1.5-$-, and 1.6 -fold $(P<0.05)$ respectively, Fig. 5B), compared to $0 \mathrm{G}$ controls and 20E2. The total $\mathrm{I}_{\mathrm{sc}}$ in the presence of forskolin in OVX females with $20 \mathrm{E} 2$ was significantly less than with $600 \mathrm{G}$ (reduced by $28 \%$, Fig. 5B). The total $\mathrm{I}_{\mathrm{sc}}$ in the presence of forskolin in OVX females with $10 \mathrm{E} 2$ was as significantly increased as with $600 \mathrm{G}$ (Fig. 5B). These data suggest that in the absence of endogenous estrogen (i.e. OVX females), 10E2 and 600G act similarly to increase intestinal basal and total $\mathrm{I}_{\mathrm{sc}}$ in the presence of forskolin-mediated $\mathrm{Cl}^{-}$secretion. However, in comparison, a higher dose of $\mathrm{E} 2$ (i.e. 20E2) has no effect on basal and total $\mathrm{I}_{\mathrm{sc}}$ in the presence of forskolin.

\section{Discussion}

Flavonoids (such as genistein) are found naturally in soy and plants and are digested in an average daily diet. Soy-rich diets have been shown to generate micromolar serum 


\section{Cellular Physiology Cell Physiol Biochem 2012;30:137-150 \\ \begin{tabular}{ll|l} 
and BiOChemistry $10.1159 / 000339053$ & $\begin{array}{l}\text { C 2012 S. Karger AG, Basel } \\
\text { www.karger.com/cpb }\end{array}$ \\
\cline { 2 - 3 } & Published online: June 18, 2012 & Al-Nakkash: Genistein: Sex-dependent Mechanisms of Action in Jejunum
\end{tabular}}

genistein concentrations in humans [25]. Serum genistein concentrations of $1 \mu \mathrm{mol} / \mathrm{L}$ can be obtained in rats consuming a diet containing $750 \mu \mathrm{g}$ genistein/g/day [26]. More recently, Bhandari et al. [27], showed a relationship between dietary genistein and serum levels in mice $(1000 \mathrm{mg} / \mathrm{kg}$ dietary genistein generated $\sim 1.5 \mu \mathrm{mol} / \mathrm{L}$ serum genistein and 500 $\mathrm{mg} / \mathrm{kg}$ dietary genistein generated $\sim 0.5 \mu \mathrm{mol} / \mathrm{L}$ serum genistein) after four weeks on their respective diets. We have previously demonstrated that daily sc. administration of genistein (600G) for a period of 1- or 2-weeks in mice induces significant increases in $\mathrm{Cl}^{-}$secretion in freshly isolated jejuna segments [13]; 600G increases basal $\mathrm{I}_{\mathrm{sc}}$ (compared to $0 \mathrm{G}$ ) in female mice after 1-week $\left(\sim 82 \mu \mathrm{A} / \mathrm{cm}^{2}, \mathrm{n}=15, P<0.01\right)$ and in male mice after 2-weeks $(\sim 86 \mu \mathrm{A} /$ $\left.\mathrm{cm}^{2}, \mathrm{n}=5, P<0.01\right)$. These increases in $\mathrm{I}_{\mathrm{sc}}$ were associated with concomitant increases in serum genistein levels; significantly increased in 600G females (1-week $=8.8 \pm 2.1 \mu \mathrm{M}(\mathrm{n}=$ 5), $P<0.05)$ and $600 \mathrm{G}$ males (2-weeks $=4.2 \pm 0.5 \mu \mathrm{M}(\mathrm{n}=4), P<0.05)$ compared to their respective $0 \mathrm{G}$ controls.

The intracellular signaling pathways involved in mediating these genistein-stimulated increases in jejunal secretion remain unknown. Recently, Tuo et al. [16] provided convincing evidence to demonstrate that acute serosal application of genistein $(50 \mu \mathrm{M})$ stimulated duodenal $\mathrm{HCO}_{3}^{-}$secretion, primarily through an estrogen receptor PI3K-dependent pathway, as indicated by the significant inhibition with either the PI3K inhibitor (LY294002, $20 \mu \mathrm{M}$ ) or the non-specific ER antagonist (ICI182,780, $10 \mu \mathrm{M}$ ). Within the intestinal epithelium, cAMP and adenylate cyclase have long been described as important regulators of ion transport (secretion) in rodent models and intestinal epithelial cell systems [28, 29]. Multiple isoforms of adenylyl cyclase have been reported in intestinal epithelium, moreover, their expression and regulation is modified via various signaling pathways including nitric oxide, in colonic epithelium [30, 31].

Regulation of intestinal transport by female sex hormones has also been described. Singh et al. [32] reported that $17 \beta$-estradiol (E2) caused a rapid and reversible inhibition of forskolin-stimulated chloride secretion across T84 epithelial cell monolayers. The difference in response by E2 on forskolin-stimulated chloride secretion in T84 monolayers, and our observations with genistein injections could be due to; (i) they used a concentration of forskolin $(10 \mu \mathrm{M})$ which generally elicits a maximal CFTR-mediated current [33] which is not further potentiated, (ii) it is likely that E2 (like genistein [34]) has a biphasic stimulatory and inhibitory effect, and (iii) the cell systems used are different and thus may likely involve alternative pathways in either system. Additionally, female hormones, progesterone and estradiol, have been shown to inhibit CFTR-mediated ion transport in PANC-1 pancreatic epithelial cells [35], and inhibitory effects of progesterone have been shown on cAMPmediated chloride transport in T84 intestinal cells [36].

Gender-dependent effects of E2 have been reported in rat distal colon, whereby E2 was observed to increase free intracellular $\mathrm{Ca}^{2+}$, mediated via PKC and PKA, in isolated female (but not male) rat colonic crypts [37]. These gender-dependent effects of E2 were subsequently linked to a non-genomic inhibition of female (but not male) rat colonic $\mathrm{Cl}^{-}$ secretion mediated via $\mathrm{Ca}^{2+}$ and PKC activation [38]. Condliffe et al. [38] hypothesized that the inhibitory action of $\mathrm{E} 2$ on female rat distal colonic $\mathrm{Cl}^{-}$secretion was likely mediated via inhibition of basolateral $\mathrm{K}_{\mathrm{Ca}}$ and /or CFTR channel activity, and may likely be responsible for E2-induced water and salt retention.

Phytoestrogens such as genistein play an ever evolving role in intestinal transport. Genistein has been shown to rapidly and reversibly inhibit carbachol-induced colonic activity in human colonic segments mediated via ER $\beta$ and to involve p38/mitogen activated protein kinase mediated induction of nitric oxide [39]. Acute application of genistein has been shown to stimulate electrogenic $\mathrm{Cl}^{-}$secretion across male murine jejunum [20]. The present study measures the effects of genistein after its administration in vivo. These data indicate that the effects of genistein must have persisted in vitro (for at least the experimental duration of 1.5 hours), since genistein was not administered during the measures of $\mathrm{I}_{\mathrm{sc}^{*}}$ Given the evidence 


\section{Cellular Physiology Cell Physiol Biochem 2012;30:137-150 \\ \begin{tabular}{ll|l} 
and Biochemistry & $\begin{array}{l}\text { DOI: 10.1159/000339053 } \\
\text { Published online: June 18, } 2012\end{array}$ & $\begin{array}{l}\text { C 2012 S. Karger AG, Basel } \\
\text { www.karger.com/cpb }\end{array}$ \\
\cline { 2 - 3 } Al-Nakkash: Genistein: Sex-dependent Mechanisms of Action in Jejunum
\end{tabular}}

from the literature and our own previous studies demonstrating genistein's action on CFTR in vitro $[34,40]$, we previously predicted that at least one pathway that could be involved in mediating genistein's stimulatory action on the $\mathrm{I}_{\mathrm{sc}}$ would be a potentiative action on the $\mathrm{CFTR} \mathrm{Cl}^{-}$channel itself; either increasing channel activity or channel localization, or perhaps both $[13,41]$. Our recent findings suggest that genistein-mediated increases in basal $\mathrm{I}_{\mathrm{sc}}$ can be attributed to a modest $5 \%$ concomitant increase CFTR localization in male jejunum (not females), suggesting that other mechanisms are playing more important roles in delivering these genistein-mediated increases in basal $\mathrm{I}_{\mathrm{sc}}$ in mice [13].

The role of endogenous and exogenously applied sex hormones and/or genistein on intestinal function remains ambiguous. Thus, this study aimed to ascertain the following; (1) which intracellular signaling pathways are mediating genistein's stimulatory effects on basal and forskolin-stimulated $I_{s c^{\prime}}(2)$ whether genistein and estradiol injections have comparable effects on intestinal chloride secretion, and (3) whether the absence of endogenous sex hormones modifies the effects of genistein and estradiol on intestinal function.

Genistein is capable of binding to estrogen receptors (ER), ER $\alpha$ and ER $\beta[42,43]$, both of which are found in the intestine $[44,45]$. Thus, sex-dependent differences in intestinal epithelial function could be predicted if (i) genistein were to act via an ER-mediated pathway, and/or (ii) there were differences in the ER types/numbers present in male and female murine intestine. Gender differences have been demonstrated with regards to the colonic expression of ER $\alpha$; reduced in males compared to female rats [46]. Those previously reported findings fit with our current observation that under control conditions $(0 \mathrm{G})$ female mice have significantly increased ER $\alpha$ (normalized to actin) expression compared to their male counterparts, but have similar ER $\beta$ expression. Manipulation of protein expression by genistein and $17 \beta$-estradiol treatment has been established in other cell systems. First, pretreatment of baby hamster kidney cells with genistein $(30 \mu \mathrm{m})$ for 24 hours augmented CFTR maturation and localization to the cell surface [47]. Second, treatment of human bronchiolar epithelial cells, CFBE41o(-), with 17 $\beta$-estradiol for 6-12 hours increased functional expression of $\Delta$ F508-CFTR, mediated via an increase in $\mathrm{Na}^{+} / \mathrm{H}^{+}$-exchanger regulatory factor 1 (NHERF1) expression [48]. Conversely, genistein has been shown to have stimulatory effects on protein function in the absence of changes in protein expression, for example: genistein has been shown to have little effect on P-glycoprotein expression whilst significantly stimulating P-glycoprotein-mediated efflux in colon carcinoma LS-180V cells [49].

Flavonoids have been reported to modify gene expression. Genistein has been shown to up-regulate expression of genes either through the estrogen response element (EREdependent mechanisms) or via ERE-independent mechanisms. Genistein has been documented to increase metallothionein expression in the human intestinal cells, Caco2 , and expression persisted for at least 24 hours following removal of genistein from the cell culture medium $[50,51]$. It is likely that metallothionein expression in that Caco- 2 cell system is regulated by other factors; trace minerals, cytokines, glucocorticoid and oxidative stress, and not ERE-dependent mechanisms [51]. In osteoblastic cells, genistein is proposed to modulate bone remodeling through ER's via a mechanism involving regulation of target gene expression, via decreased cAMP regulatory element transcription [52]. Interestingly, Chang et al. [53] provided evidence that genistein is a ligand for gene expression regulation by either ER $\alpha$ or ER $\beta$, and that the gene expression is modified by ligand dose, and the ability of the ligand ER complexes to enlist various coregulators at ER binding sites. Future studies will determine whether our observed genistein-mediated $\mathrm{ER} \alpha$-dependent effects (on the $\mathrm{I}_{\mathrm{sc}}$ in male mice), are mediated via ERE-dependent or -independent mechanisms.

Gender-related differences in physiology and therefore pathophysiology have been a growing focus of interest in recent years. Differences in protein expression levels in male versus female counterparts have been documented in the following studies. Female human hearts have reduced expression of a number of repolarizing $\mathrm{K}^{+}$channel subunits (Kv.14, 


\section{Cellular Physiology Cell Physiol Biochem 2012;30:137-150 \\ \begin{tabular}{ll|l} 
and Biochemistry & $\begin{array}{l}\text { DOI: 10.1159/000339053 } \\
\text { Published online: June 18, 2012 }\end{array}$ & $\begin{array}{l}\text { O 2012 S. Karger AG, Basel } \\
\text { www.karger.com/cpb }\end{array}$ \\
\cline { 2 - 3 } Al-Nakkash: Genistein: Sex-dependent Mechanisms of Action in Jejunum
\end{tabular}}

kir2.3, Kir6.2 etc), with potentially important roles in susceptibility to cardiac arrhythmias [54]. We have recently demonstrated a gender-dependent difference in jejunum epithelial basolateral $\mathrm{K}^{+}$channels (known to be involved in recycling of $\mathrm{K}^{+}$, and essential to establish an optimal electrical potential for $\mathrm{Cl}^{-}$secretion); $\mathrm{K}_{\mathrm{Ca}}$-mediated basal $\mathrm{I}_{\mathrm{sc}}$ was greater in $0 \mathrm{G}$ males than $0 \mathrm{G}$ females by 2 -fold, indicating a gender effect whereby $\mathrm{K}_{\mathrm{Ca}}$ may play a more important role in intestinal secretion in males versus females. Similar gender-dependent differences in ion channel contribution towards tissue function have been described by other investigators in other tissues, e.g. a role for voltage-dependent $\mathrm{K}^{+}$channels in adenosinemediated relaxation of coronary arterioles from male (not female) swine [55]. Inhibitory effects of $17 \beta$-estradiol on female (not male) rat distal colonic crypts have been postulated to be mediated by inhibition of basolateral $\mathrm{K}^{+}$channels, KCNQ1, via PKC $\delta$ - and PKA-dependent pathways $[46,56,57]$. It has been postulated that this anti-secretory response to estrogen may be representative of whole body salt and water retention during specific parts of the menstrual cycle. Whilst we did not quantify stool "fluidity" (i.e. water content) in this study, it is certainly of interest for future studies.

The cellular pathways responsible for generating the genistein- or estradiol-mediated increases in basal $\mathrm{I}_{\mathrm{sc}}$ remain unclear. We show here that genistein (600G) appears to act via stimulation of adenylate cyclase in female mice, and ER $\alpha$ in male mice. Furthermore, removal of endogenous sex hormones (i.e. orchiectomy) produces differential effects in both sexes. The response to both intact and OVX females to 600G was a 1.7-fold increase in basal $\mathrm{I}_{\mathrm{sc}}$ whereas the response to $600 \mathrm{G}$ in males was not maintained in the CAST group (i.e. no effect) compared to the intact group (1.9-fold increase). These data suggest a gender-dependent requirement for endogenous sex hormones for maximal 600G-mediated increases in basal $I_{\text {sc }}$ (not essential for females, but essential for males).

This study provides evidence that s.c. injections of genistein (600G) increase basal (and total $\mathrm{I}_{\mathrm{sc}}$ in the presence of forskolin) intestinal secretion, utilizing sex-dependent mechanisms of action. Whilst the complete mechanism(s) of action of genistein mediating this effect are unclear, we can attribute the majority of this effect to an activation of ER $\alpha$ (in males) and adenylate cyclase (in females), which contributes towards the increase in the genistein-activated $I_{s c}$ in both sexes. Whilst this work furthers our understanding of the role and mechanism(s) of action of genistein on jejuna $I_{\text {sc }^{\prime}}$ future studies will further elucidate the intracellular mechanism(s) involved in murine male and female genistein-stimulated jejunal secretion.

\section{Acknowledgements}

The author would like to thank Lyn Batia, Amity Peterson and Lana Leung (Midwestern University) for technical assistance, Dr. R. MacDonald (Iowa State University, Department of Nutrition) and Dr. T Broderick (Midwestern University) for helpful discussion. This work was supported by the National Institutes of Health [Grant R15 DK071625-01A2 to L.A.].

\section{References}

1 Murphy PA: Phytoestrogen content of processed soybean products: Food Technol 1982;36:60-64.

2 Cassidy A, Griffin B: Phyto-estrogens: a possible role in the prevention of CHD? Proc Nutr Soc1999;58:193199.

3 Morito K, Hirose T, Kinjo J, Hirakawa T, Okawa M, Nohara T, Ogawa S, Inoue S, Muramatsu M, Masamune Y: Interaction of phytoestrogens with estrogen receptors alpha and beta. Biol Pharm Bull 2001;24:351-356. 


\section{Cellular Physiology Cell Physiol Biochem 2012;30:137-150 \begin{tabular}{ll|l} 
and BiOchemistry $10.1159 / 000339053$ & $\begin{array}{l}\text { DO 2012 S. Karger AG, Basel } \\
\text { Published online: June 18, } 2012\end{array}$ & $\begin{array}{l}\text { www.karger.com/cpb } \\
\text { wwem }\end{array}$
\end{tabular} \\ Al-Nakkash: Genistein: Sex-dependent Mechanisms of Action in Jejunum}

4 Suetsugi M, Su L, Karlsberg K, Yuan YC, Chen S: Flavone and isoflavone phytoestrogens are agonists of estrogen-related receptors. Mol Cancer Res 2003;1:981-991.

5 Morito K, Aomori T, Hirose T, Kinjo J, Hasegawa J, Ogawa S, Muramatsu M, Masamune Y: Interaction of phytoestrogens with estrogen receptors alpha and beta (II). Biol Pharm Bull 2002;25:48-52.

6 Jacobs MN, Dickins M, Lewis D: Homology modeling of the nuclear receptors: human oestrogen receptor beta (hERbeta), the human pregnane-X-receptor (PXR), the Ah receptor (AhR) and the constitutive adrostane receptor (CAR) ligand binding domains from the human oestrogenreceptor alpha (hERalpha) crstal structure, and the human peroxisome proliferator activated receptor alpha (PPARalpha) ligand binding domain from the huamn PPARgamma crystal structure. J Steroid Biochem Mol Biol 2003;84:117132.

7 Wada-Hiraike O, Imamov 0, Hiraike H, Hultenby K, Schwend T, Omoto Y, Warner M, Gustafsson J-A: Role of estrogen receptor B in colonic epithelium. . Proc Natl Acad Sci USA 2006;103:2959-2964.

8 Gejima K, Kawaguchi H, Souda M, Kawashima H, Komakata T, Hamada N, Umekita Y, Sakata R, Yoshida H: Expression of estrogen receptor-alpha protein in the rat digestive tract. In Vivo 2007;21:487-492.

9 Kramer F, Johnson IT, Doleman JF, Lund EK: A comparison of the effects of soya isoflavonoids and fish oil on cell proliferation, apoptosis and the expression of oestrogen receptors alpha and beta in the mammary gland and colon of the rat. Br J Nutr 2009;102:29-36.

10 Kawano N, Koji T, Hishikawa Y, Murase K, Murata I, Kohno S: Identification and localization of estrogen receptor alpha- and beta-postive cells in adult male and female mouse intestine at various estrogen levels. Histochem Cell Biol 2004;121:399-405.

11 Al-Nakkash L, Clarke LL, Rottinghaus GE, Chen YJ, Cooper K, Rubin LJ: Dietary genistein stimulates anion secretion across female murine intestine. J Nutr 2006;136:2785-2790.

$12 \mathrm{Xu} \mathrm{X}$, Wang H, Murphy P, Cook L, Hendrich S: Daidzein is a more bioavailable soymilk isoflavone than is genistein in adult women. J Nutr 1994;124:825-832.

13 Al-Nakkash L, Batia L, Bhakta M, Peterson A, Hale N, Skinner R, Sears S, Jensen J: Stimulation of murine intestinal secretion by daily genistein injections: gender-dependent differences. Cell Physiol Biochem 2011;28:239-250.

14 Noel S, Strale P-O, Dannhoffer L, Wilke M, DeJonge H, Rogier C, Mettey Y, Becq F: Stimulation of salivary secretion in vivo by CFTR potentiators in $\mathrm{Cftr}^{+/+}$and $\mathrm{Cftr}^{-/}$mice. J Cyst Fibros2008;7:128-133.

15 Tuo B, Wen G, Seidler U: Differential activation of the $\mathrm{HCO}_{3}$ - conductance through the cystic fibrosis transmembrane conductance regulator anion channel by genistein and forskolin in murine duodenum. $\mathrm{Br} \mathrm{J}$ Pharm 2009;158:1313-1321.

16 Tuo B, Wen G, Song P, Xu J, Liu X, Seidler U, Dong H: Genistein stimulates duodenal $\mathrm{HCO}_{3}{ }^{-}$secretion through PI3K pathway in mice. Eur J Pharmacol 2011;651:159-167.

17 Clarke LL, Harline MC: Dual role of CFTR in cAMP-stimulated $\mathrm{HCO}_{3}^{-}$secretion across murine duodenum. Am J Physiol 1998;274:G718-G726.

18 Goddard CA, Evans M, Colledge W: Genistein activates CFTR-mediated Cl- secretion in the murine trachea and colon. Am J Physiol 2000;279:C383-C392.

19 Grubb BR: Ion transport across the jejunum in normal and cystic fibrosis mice. Am J Physiol 1995;268:G505-G513.

20 Baker MJ, Hamilton KL: Genistein stimulates electrogenic $\mathrm{Cl}^{-}$secretion in the mouse jejunum. Am J Physiol 2004;287:C1636-C1645.

21 Chao P-C, Hamilton KL: Genistein stimulates electrogenic $\mathrm{Cl}^{-}$secretion via phosphodiesterase modulation in the mouse jejunum. Am J Physiol 2009;297:C688-698.

22 Clarke LL, Grubb BR, Gabriel SE, Smithies O, Coller BH, Boucher RC: Defective epithelial chloride transport in a gene-targeted mouse model of cystic fibrosis. Science 1992;257:1125-1128.

23 Clarke LL, Harline MC: CFTR is required for cAMP inhibition of intestinal $\mathrm{Na}^{+}$absorption in a cystic fibrosis mouse model. Am J Physiol 1996;270:G259-G267.

24 Sheldon RJ, Malarchik ME, Fox DA, Burks TF, Porreca F: Pharmacological characterization of neural mechanisms regulating mucosal ion transport in mouse jejunum. J Pharmacol Exp Ther 1988;249:572-582.

25 Hendrich S, Lee KW, Xu X, Wang HJ, Murphy PA: Defining food components as new nutrients. J Nutr 1994;124:1789S-1792S.

26 Santell RC, Chang YC, Nair MG, Helferich WG: Dietary genistein exerts estrogenic effects upon the uterus, mammary gland and the hypothalamic/pituitary axis in rats. J Nutr 1997;127:263-269. 


\section{Cellular Physiology Cell Physiol Biochem 2012;30:137-150 \\ \begin{tabular}{ll|l} 
and BiOchemistry 10.1159/000339053 & $\begin{array}{l}\text { C 2012 S. Karger AG, Basel } \\
\text { Published online: June 18, } 2012\end{array}$ & \begin{tabular}{l} 
www.karger.com/cpb \\
\cline { 2 - 2 }
\end{tabular}
\end{tabular} \\ Al-Nakkash: Genistein: Sex-dependent Mechanisms of Action in Jejunum}

27 Bhandari A, Crawford SE, Huang L, Reenstra WW: Effects of oral genistein in mice. Pediatr Pathol Mol Med 2003;22:131-141.

28 Rachmilewitz D, Karmell F: Effect of colchicine on jejunal adenylate cyclase activity, PGE2 and cAMP contents. Eur J Pharmacology 1980;67:235-239.

29 Cliff WH, Frizzell R: Separate $\mathrm{Cl}^{-}$conductances activated by cAMP and $\mathrm{Ca}^{2+}$ in $\mathrm{Cl}^{-}$secreting epithelial cells. Proc Natl Acad Sci USA 1990;87: 4956-4960.

30 Freeman SL, MacNaughton WK: Nitric oxide inhibitable isoforms of adenylate cyclase mediate epithelial secretory dysfunction following exposure to ionising radiation. Gut 2004;53:214-221.

31 Choi LJ, Jenikova G, Hanson E, Spehlmann ME, Boehling NS, Kirstein SL, Bundley RA, Smith JR, Insel PA, Eckman L: Coordinate down-regulation of adenylyl cyclase isoforms and the stimulatory G protein (Gs) in intestinal epithelial cells. J Biol Chem 2010;285:12504-12511.

32 Singh AK, Schultz BD, Katzenellenbogen JA, Price EM, Bridges RJ, Bradbury NA: Estrogen inhibition of cystic fibrosis transmembrane conductance regulator-mediated chloride secretion. J Pharmacol Exp Ther 2000;295:195-204.

33 Al-Nakkash L, Hwang T-C: Activation of wild-type and $\Delta$ F508-CFTR by phosphodiesterase inhibitors through cAMP-dependent and -independent mechanisms. Pflugers Arch 1999;437:553-561.

34 Wang F, Zeltwanger S, Yang I, Nairn A, Hwang T-C: Actions of genistein on CFTR channel gating. J Gen Physiol 1998;111:477-490.

35 Sweezey NB, Gauthier C, Gagnon S, Ferretti E, Kopelman H: Progesterone and estradiol inhibit CFTRmediated ion transport by pancreatic epithelial cells. Am J Physiol 1996;271:G747-G754.

36 Mayol JM, Arbeo-Escolar A, Alarma-Estrany P, Adame-Navarrete Y, Fernandez-Repressa JA: Progesterone inhibits chloride transport in human intestinal epithelial cells. World J Surg 2002;26:652-656.

37 Doolan CM, Condliffe SB, Harvey BJ: Rapid non-genomic activation of cytosolic cyclic AMP-dependent protein kinase activity and $\left[\mathrm{Ca}^{2+}\right]_{i}$ by $17 \beta$-oestradiol in female rat distal colon. Br J Pharmacol 2000;129:1375-1386.

38 Condliffe SB, Doolan CM, Harvey BJ: 17Beta-oestradiol acutely regulates Cl- secretion in rat distal colonic epithelium. J Physiol 2001;530.1:47-54.

39 Hogan AM, Collins D, Sheehan K, Zierau O, Baird AW, Winter DC: Rapid effects of phytoestrogens on human colonic smooth muscle are mediated by oestrogen receptor beta. Mol Cell Endocrinol 2010;320:106-110.

40 Illek B, FIscher H, Santos GF, Widdicombe JH, Machen TE, Reenstra WW: cAMP-independent activation of CFTR Cl channels by the tyrosine kinase inhibitor genistein. Am J Physiol 1995;268:C886-C893.

41 Lim CH, Bijvelds MJ, Nigg A, Schoonederwoerd K, Houtsmuller AB, De Jonge HR, Tilly BC: Cholesterol depletion and genistein as tools to promote F508delCFTR retention at the plasma membrane. Cell Physiol Biochem 2007;20:473-482.

42 So FV, Guthrie N, Chambers AF, Carroll KK: Inhibition of proliferation of estrogen receptor-positive MCF7 human breast cancer cells by flavonoids in the presence and absence of excess estrogen. Cancer Lett 1997;112:127-133.

43 Zava DT, Duwe G: Estrogenic and antiproliferative properties of genistein and other flavonoids in human breast cancer cells in vitro. Nutr Cancer 1997;27:31-40.

44 Campbell-Thompson ML: Estrogen receptor alpha and beta expression in upper gastrointestinal tract with regulation of trefoil factor family 2 mRNA levels in ovariectomized rats. Biochem Biophys Res Commun 1997;240:478-483.

45 Campbell-Thompson M, Lynch IJ, Bhardwaj B: Expression of estrogen receptor (ER) subtypes and ERbeta isoforms in colon cancer. Cancer Res 1999;61:632-640.

46 46. O'Mahony F, Alzamora R, Chung H-L, Thomas W, Harvey BJ: Genomic priming of the antisecretory response to estrogen in rat distal colon throughout the estrous cycle. Mol Endocrinol 2009;23:1885-1899.

47 Schmidt A, Hughes LK, Cai Z, Mendes F, Li H, Sheppard DN, Amaral MD: Prolonged treatment of cells with genistein modulates the expression and function of the cystic fibrosis transmembrane conductance regulator. Br J Pharm 2008;153:1311-1323.

48 Fanelli T, Cardone RA, Favia M, Guerra L, Zaccolo M, Monterisi S, De Santis T, Riccardi SM, Reshkin SJ, Casavola V: Beta-oestradiol rescues deltaF508CFTR functional expression in human cystic fibrosis airway CFBE41o(-) cells through upregulation of NHERF1. Biol Cell 2008;100:399-412.

49 Okura T, Ibe M, Umegaki K, Shinozuka K, Yamada S: Effects of dietary ingredients on function and expression of P-glycoprotein in human intestinal epithelial cells. Biol Pharm Bull 2010;33:255-259. 


\section{Cellular Physiology Cell Physiol Biochem 2012;30:137-150 and Biochemistry \begin{tabular}{l|l}
\hline DOI: $10.1159 / 000339053$ & $\begin{array}{l}\text { C 2012 S. Karger AG, Basel } \\
\text { www.karger.com/cpb }\end{array}$ \\
Published online: June 18, 2012 & wwing
\end{tabular}}

50 Kuo SM, Leavitt PS: Genistein increases metallothionein expression in human intestinal cells, Caco-2. Biochem Cell Biol 1999;77:79-88.

51 Hua P, Tsai WJ, Kuo SM: Estrogen response element-independent regulation of gene expression by genistein in intestinal cells. Biochim Biophys Acta 2003;1627:63-70.

52 Tang X, Zhu X, Liu S, Wang S, Ni X: Isoflavones supress cyclic adenosine 3',5'-monophosphate regulatory element-mediated transcription in osteoblastic cell line. J Nutr Biochem 2011;22:865-873.

53 Chang EC, Charn TH, Park SH, Helferich WG, Komm B, Katzenellenbogen JA, Katzenellenbogen BS: Estrogen receptors alpha and beta as determinants of gene expression: influence of ligand, dose, and chromatin binding. Mol Endocrinol 2008;22:1032-1043.

54 Gaborit N, Varro A, Le Bouter S, Szuts V, Escande D, Nattel S, Demolombe S: Gender-related differences in ion channel and transporter subunit expression in non-diseased human hearts. J Mol Cell Cardiol 2010;49:639-646.

55 Heaps C, Bowles D: Gender-specific $\mathrm{K}^{+}$-channel contribution to adenosine-induced relaxation in coronary arterioles. J Appl Physiol 2002;92:550-558.

56 O’Mahony F, Alzamora R, Betts V, LaPaix F, Carter D, Irnaten M, Harvey BJ: Female gender-specific inhibition of KCNQ1 channels and chloride secretion by $17 \beta$-estradiol in rat distal colonic crypts. J Biol Chem 2007;282:24563-24573.

57 Alzamora R, O'Mahony F, Harvey BJ: Estrogen inhibits chloride secretion caused by cholera and Escherichia coli enterotoxins in female rat distal colon. Steroids 2011;76:867-876. 